\title{
FDI PERFORMANCE TO EXPLORE THE GROWTH OF THE INDIAN ECONOMY
}

\author{
R. LAVANYA KUMARI \\ Associate Professor, Department of Master of Business Administration, Loyola UG \& PG Academy,
}

Secunderabad, Telangana, India

\begin{abstract}
India's foreign Direct Investment (FDI) is a driving motive force of the country's growth of the economy for the reason that monetary liberalization of 1991, overseas investments into the country have enhanced notably. FDI rules and regulations have been often mitigate through the years with a purpose to draw and promote India's FDI. India is a beneficial investment destination for foreign traders given its exceedingly lower wages and unique funding privileges in the type of tax exemptions etc. foreign direct fairness inflows are the sum of inward direct investments into a rustic with the aid of non-resident or foreign traders. An overseas direct funding is made via an entity now not dwelling within the united states the investment is being made in. This funding is characterized by way of a controlling business possession. Consequently, Foreign Direct investment (FDI) is different from Foreign Portfolio Investment (FPI) through the belief of direct manipulate. Overseas direct funding includes "mergers \& acquisitions, building new centres, reinvesting income earned from distant places operations and intra business enterprise loans" which generally includes participation in management, joint-ventures, generation transformation, and expertise. To conclude FDI in India assists a bridge gap among distant places traders and investment chances.

KEYWORDS: Entry Routes, FDI, Types of FDI, Methods and Performance of FDI
\end{abstract}

Received: Apr 15, 2020; Accepted: May 06, 2020; Published: Jun 30, 2020; Paper Id.: IJMPERDJUN2020188

\section{INTRODUCTION}

Notwithstanding India places nowadays because the most important democracy, it's administrative additionally because the political found out has many flaws and shortcomings. The management and the system of governance of India is impregnated with flaws like shortages of energy, bureaucratic hassles, political uncertainty, and infrastructural deficiencies. In spite of these political shortcomings, India is seemed to be one a few of the predominant lucrative grounds for investing, in the eyes of the wealthy Europeans and also American buyers. That is frequently fact purpose that why the increasingly more overseas traders coming to India and investing liberally into the numerous sectors of the financial system in India. India is the constructive united states in continuing to be one of the worldwide preferred FDI destinations in 2020 at the returned of the government liberalised norms and a huge soar in the ease of doing enterprise rating. The healthful increase within the foreign places investments is proving more optimism India in particular draws investments from international locations like Mauritius, Singapore, Japan, the United Kingdom, the Netherlands, America, Germany, Cyprus, France, and also the UAE. The sectors that received most FDI include offerings, hardware and software, production development, trading, car, pharmaceuticals, chemicals, and energy.

India is the optimistic country in continuing to be one of the global favourites FDI destinations in 2020 on the back of the government's liberalised norms and a significant jump in the ease of doing business ranking. The 
healthy growth within the overseas investments is proving more optimism India mainly attracts investments from countries like Mauritius, Singapore, Japan, the UK, the Netherlands, the US, Germany, Cyprus, France, and also the UAE. The sectors that received maximum FDI include services, hardware and software, construction development, trading, automobile, pharmaceuticals, chemicals, and power. To boom the foreign direct investment in India there are major industrialists and business tycoons who expanded their businesses in India. The major investors for the growth of the Indian economy are such as Lee Kim Tah holdings, Salim group - Indonesia, Edaw Ltd- USA, Emaar group - Dubai, IJM, CESMA International private ltd, Ho Hup Construction Co - Malaysia, Evan Lim and Keppel Land - Singapore etc., Japanese \& Korean firms such as Suzuki, Hyundai \& Daichi are the foreign investors who have always trusted investing in the sectors like automobiles as well as pharmaceuticals. Many of the Indian sectors are benefited from these Foreign Direct Investment in turn given the lucrative returns to the investors as the reason why the most of them looking towards India as a venue for investment.

\section{India Entry Routes of FDI}

In India FDI is permitted through two routes which can be accessed through the Automatic Route or Government Route as follows:

- Automatic Route: In this route the Indian enterprise could not want any prior approval from the government for investments in the country which means foreign direct funding opportunities are frequently met without any initial approval from the government of India.

- Government Route: In this route, an approval from the Indian authorities is required earlier than making an investment. Opportunities for foreign investments given by the government are taken into consideration with the aid of respective Administrative Ministry Department. Right here, the technique of overseas investments for an Indian corporation ought to get approval from the authorities of India and exclusive cabinets.

\section{Types of FDI}

In India obtaining funds through FDI can be an overwhelming process which can simplify with the following types.

- Horizontal FDI: This kind of FDI emerges while a business replicates its domestic country-based activities of the commercial enterprise within identical valued extraordinarily in the sovereign country in which the investment is energy.

- Vertical FDI: It occurs while eEnterprise through foreign direct funding movements in a ascending or descending in varied price chains.

- Platform FDI: It comes while FDI is a supply into a destination country is observed through the need of tranship to a third country.

\section{Methods of FDI}

The foreign direct investor may obtain voting power of an enterprise in an economy through any of the following methods:

- Includes a completely owned subsidiary or firm anywhere

- Obtaining shares in an associated organisation 
- Through a merger or an acquisition of a company that is not associated

- Part in a fairness joint challenge with every different investor

\section{PERFORMANCE OF FDI INFLOWS}

India positioned has retained because of the world's fastest growing major economy. It's proud that US \$2.6trn is that the world's 6th largest economy accounting to 15 of worldwide growth and therefore the country surge ahead to become a US \$ 5 trn economy by 2025. Globally, India is ranking among the foremost developed economies within the next decade as India's young workforce is gearing up to play a big role within the driving economic progress, labour productivity improving, enhancing domestic manufacturing \& revenue from services, strengthening indigenous innovations and increasing India's purchasing power. The Indian economy is operated by three main categories like Agriculture, Services and Manufacturing various numbers of sectors or industries are covered under these categories. For the aim of this paper ten key sectors are identified as those which are emerging ahead and even have the potentiality to make the pillars of the world's largest economies within the years ahead.

Table 1: FDI Equity Inflows (Month-Wise) During the Financial Year 2019-2020

\begin{tabular}{|c|l|c|c|}
\hline \multicolumn{2}{|c|}{ (Rs. Crore) } & \multicolumn{2}{c|}{ Amount } \\
\hline \multicolumn{2}{|c|}{ (In US\$ mn) } \\
\hline 1. & April, 2019 & 36,463 & 5,252 \\
\hline 2. & May, 2019 & 26,481 & 3,795 \\
\hline 3. & June, 2019 & 50,567 & 7,282 \\
\hline 4. & July, 2019 & 30,774 & 4,472 \\
\hline 5. & August, 2019 & 18,164 & 2,553 \\
\hline 6. & September, 2019 & 19,551 & 2,741 \\
\hline T. Total & 22,808 & 3,211 \\
\hline 8. & October, 2019 & 20,036 & 2,804 \\
\hline 9. & Devember, 2019 & 33,166 & 4,659 \\
\hline \multicolumn{2}{|c|}{} & & \\
\hline $2019-20$ (form April, 2019 to December, 2019) * & $\mathbf{2 5 8 , 0 0 9}$ & $\mathbf{3 6 , 7 6 9}$ \\
\hline 2018-19 (form April, 2018 to December, 2018) * & $\mathbf{2 3 3 , 2 6 3}$ & $\mathbf{3 3 , 4 9 2}$ \\
\hline \% of Growth Over Last Year & $\mathbf{( + ) ~ 1 1 \%}$ & $\mathbf{( + ) ~ 1 0 \%}$ \\
\hline
\end{tabular}

Note: * Figures are provisional, subject to reconciliation with RBI. Source: www.rbi.org

The below table show the information regarding sectors, India's construction enterprise is worth US\$ 130 billion is a few of the twelfth champion sectors recognized by the India's government which focus on actual property and development of urban segments namely real estate, spans residential, workplace, retail, resorts and enjoyment parks, whereas the development of urban phase covers regions together with water supply, sanitation, healthcare, urban shipping, and educational institutions. The sector implementation witnessed towards the reforms inclusive of GST, RERA, IBC, put up which changed into a variety of FDI into India.

India is the principal biggest issuer of widespread drugs globally. The country is a primary producer of diverse critical, low-price pharmaceutical merchandise for each, the Indian and global marketplace. India's strengths consist of the united country's cost of production low, large biotech body of workers, scientists, engineers and managerial skills. Currently India exported of 35.82 lakh medication of hydroxychloroquine to the US in conjunction with 9 metric tons of active pharmaceutical ingredient or API required within the producing of the drug for the corona virus ailment 2019 (COVID-19) and for numerous vaccines India also materials 50-60\% of demand globally, less costly Anti-Retroviral (ARV) capsules from India had been a major element in AIDS sufferers getting more admission to treatment. Indian 
pharma organizations at the moment are venturing into manufacturing more complex products particularly a microsphere, liposome's, emulsions and building the country's capabilities in (R\&D) research \&development.

Automobile enterprise in India specifically cantered on servicing, dealership, financing and protection of automobiles that's expected to be the world's third biggest automotive market in means of volume by 2026. Presently enterprise manufactures $25 \mathrm{mn}$ motors, of which $3.5 \mathrm{mn}$ are exported. India stands a strong role within the globally heavy motors area as its miles the wide-ranging tractor producer, secondly wide bus producer and 1/3 broadest heavy vehicles producer inside the international. The sale of passenger automobiles has multiplied by way of $2.7 \%$, two-wheeler by $4.86 \%$.

Table 2: Sector-Wise Highest FDI Equity Inflows

\begin{tabular}{|c|c|c|c|c|c|c|}
\hline Ranks & Sector & 2017-18 & 2018-19 & 2019-20 & $\begin{array}{l}\text { Cumulative } \\
\text { Inflows }\end{array}$ & $\begin{array}{l}\text { Total Inflows } \\
\text { (US\$) }\end{array}$ \\
\hline & & \multicolumn{2}{|c|}{ (April - March) } & $\begin{array}{c}\text { (April - } \\
\text { December) }\end{array}$ & & $\%$ \\
\hline 1. & Services Sector ** & $\begin{array}{l}43,249 \\
(6,709)\end{array}$ & $\begin{array}{l}63,909 \\
(9,158)\end{array}$ & $\begin{array}{l}45,813 \\
(6,521)\end{array}$ & $\begin{array}{l}462,114 \\
(80,671)\end{array}$ & 18 \\
\hline 2. & $\begin{array}{l}\text { Computer Software \& } \\
\text { Hardware }\end{array}$ & $\begin{array}{l}39,670 \\
(6,153)\end{array}$ & $\begin{array}{l}45,297 \\
(6,415)\end{array}$ & $\begin{array}{l}44,629 \\
(6,349)\end{array}$ & $\begin{array}{l}266,385 \\
(43,587)\end{array}$ & 10 \\
\hline 3 & Telecommunications & $\begin{array}{l}39,748 \\
(6,212)\end{array}$ & $\begin{array}{l}18,337 \\
(2,668)\end{array}$ & $\begin{array}{l}29,798 \\
(4,291)\end{array}$ & $\begin{array}{l}218,047 \\
(37,116)\end{array}$ & 8 \\
\hline 4. & Trading & $\begin{array}{l}28,078 \\
(4,348)\end{array}$ & $\begin{array}{l}30,963 \\
(4,462)\end{array}$ & $\begin{array}{l}24,827 \\
(3,520)\end{array}$ & $\begin{array}{l}168,426 \\
(26,542)\end{array}$ & 6 \\
\hline 5. & $\begin{array}{l}\text { Construction } \\
\text { Development } * *\end{array}$ & $\begin{array}{l}3,472 \\
(540)\end{array}$ & $\begin{array}{l}1,503 \\
(213)\end{array}$ & $\begin{array}{l}2,275 \\
(326)\end{array}$ & $\begin{array}{l}121,889 \\
(25,371)\end{array}$ & 6 \\
\hline 6. & Automobile Industry & $\begin{array}{l}13,461 \\
(2,090)\end{array}$ & $\begin{array}{l}18,309 \\
(2,623)\end{array}$ & $\begin{array}{l}17,448 \\
(2,506)\end{array}$ & $\begin{array}{l}141,437 \\
(23,893)\end{array}$ & 5 \\
\hline 7. & Chemicals** & $\begin{array}{c}8,425 \\
(1,308)\end{array}$ & $\begin{array}{l}13,685 \\
(1,981)\end{array}$ & $\begin{array}{l}6,073 \\
(860)\end{array}$ & $\begin{array}{c}97,135 \\
(17,442)\end{array}$ & 4 \\
\hline 8. & $\begin{array}{l}\text { Drugs \& } \\
\text { Pharmaceuticals }\end{array}$ & $\begin{array}{c}6,502 \\
(1,010)\end{array}$ & $\begin{array}{l}1,842 \\
(266)\end{array}$ & $\begin{array}{l}2,902 \\
(414)\end{array}$ & $\begin{array}{c}87,067 \\
(16,397)\end{array}$ & 4 \\
\hline 9. & Construction $* *$ & $\begin{array}{l}17,571 \\
(2,730)\end{array}$ & $\begin{array}{l}15,927 \\
(2,258)\end{array}$ & $\begin{array}{c}9,516 \\
(1,351)\end{array}$ & $\begin{array}{l}103,389 \\
(16,156)\end{array}$ & 4 \\
\hline 10. & Power & $\begin{array}{l}10,473 \\
(1,621)\end{array}$ & $\begin{array}{c}7,330 \\
(1,106)\end{array}$ & $\begin{array}{l}2,368 \\
(337)\end{array}$ & $\begin{array}{c}80,257 \\
(14,653)\end{array}$ & 3 \\
\hline
\end{tabular}

Amount Rs. Crores (US\$ Million)

Source: www.rbi.org

Note

- **Services sector includes Financial, Banking, Insurance, Non-Financial / Business, Outsourcing, R\&D, Courier, Tech. Testing and Analysis

- **Construction Development: Townships, housing, built-up infrastructure and construction-development projects

- $\quad * *$ Chemicals (Other than Fertilizers)

- $\quad * *$ Construction (Infrastructure) Activities

- Cumulative FDI equity inflows (from April, 2000 to December, 2019) 
- FDI Sectoral data has been revalidated / reconciled in line with the RBI, which reflects minor changes in the FDI figures (increase/decrease) as compared to the earlier published sectoral data and all the figures are provisional

\section{Market Size of FDI}

Globally, India is one of the maximum appealing FDI locations. The government often reforms foreign places investment norms so that to expand FDI investments in India. Consistently with the Department of promotion of Industry and Internal Trade (DPIIT), FDI plays massive as the country requires big investments to overtake its infrastructure region to enhance growth. During 2014-19 India's FDI were given improved to the extent of US\$ 284 from US\$ 190 billion. Foreign Direct Investment into India grew by $28 \%$ to $\$ 16.33$ billion at some point of the first area of the current fiscal, in line with government statistics. During April-June of 2018-19 the inflow of foreign direct funding (FDI) stood at 12.75 billion which attracted most overseas inflows throughout April-June 2019-20 within the sectors like services ( $\$ 2.8$ billion), computer software program and hardware ( $\$ 2.24$ billion), telecommunication ( $\$ 4.22$ billion), and products (\$1.13). Country like Singapore emerged as the most important source of FDI in India all through the primary region of the financial with $\$ 5.33$ billion investments which changed into observed by means of countries like Mauritius (\$4.67 billion), US (\$1.45 billion), Netherlands ( $\$ 1.35$ billion), and also Japan (\$472 million). The last year government cozy foreign investment norms in the sectors including retail enterprise, colliery and agreement manufacturing.

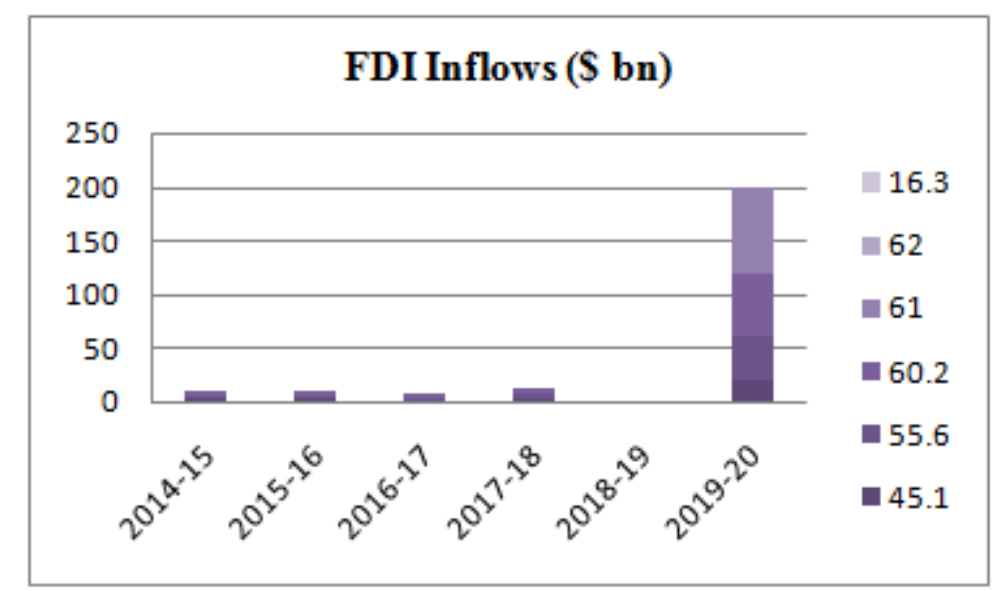

Figure 1

\section{INVESTMENTS AND DEVELOPMENTS OF FDI}

As the disaster of covid pandemic the Foreign Direct Investment is a crucial purpose pressure for the boom of the economic system and also a critical source of non-debt monetary resource for the economic improvement of India. Overseas agencies invest in India to avail advantage of in particular lower wages, precise funding privileges like exemptions of tax and lots of others. For a rustic like India in which foreign places investments are being made which moreover way accomplishing technical knowledge and employment generating. The India's government beneficial coverage regime and sturdy industrial company surroundings have ensured that overseas capital continues flowing into the country. In current years the government has taken many tasks specially rest of FDI norms throughout numerous sectors like defence, PSU oil refineries, telecom, energy, and inventory marketplace, amongst others for the reason that India has emerged one of the pinnacle recipients of Greenfield FDI inflows, a few significant inclinations in FDI India are as follows: 
- Amazon introduced investment of US\$ 1 billion in India for digitizing small and medium companies and developing 1,000,000 jobs by way of 2025 .

- MasterCard introduced its plans to invest up to US\$ 1 billion in India over next 5 years to double its R\&D efforts for the Indian marketplace.

- French oil and fuel giant have obtained a 37.4\% stake in Adani gasoline Ltd for Rs 5,662 crore (US\$ 810 million) within the year 2019 making it the largest Foreign Direct funding (FDI) in India's city gas distribution (CGD) segment.

- Reliance Industries (RIL) introduced one of India's largest FDI offers, as Saudi Aramco will purchase a $20 \%$ stake in Reliance's oil-to-chemical compounds (OTC) agency at an commercial enterprise agency price of US\$ 75 billion in the year 2019 .

- In 2018, VM ware, prime software innovating business company of US has delivered funding US\$ 2 billion in India amongst 2023 .

- Bharti Airtel acquired approval of the government of India for sale of $20 \%$ in 2018 in its DTH arm to an US based private fairness company, Warburg Pincus, for around \$350 million.

- In 2018, Idea's attraction for a 100\% FDI was approved by (DoT) Department of Telecommunication (DoT) followed by way of its Indian merger with Vodafone making Vodafone idea the superlative important telecom operator in India

- Walmart acquired a 77\% stake in Flipkart the year 2018 for an attention of US\$ 16 billion.

- The funding arm of the sector financial institution organization like world bank group- International Finance Corporation (IFC) is planning to make investments approximately US \$ 6 billionwith several sustainable and renewable electricity programmes in India in the year 2022.

\section{INITIATIVES BY THE GOVERNMENT OF INDIA}

India's government works in a scope of framework relevance on foreign investments in the nation that has often eased FDI norms across sectors in the economy, with the intention of selling FDI in India. A few recent tasks with the assistance of the government of India are:

- In 2020 Non-resident Indians (NRIs) to gather up to a 100\% stake in Air India.

- In 2019 legally sanctioned 26\% FDI in digital sectors.

- In 2019 government authorities authorized a 100\% FDI underneath the automated route in coal mining for open sale (similarly to in developing allied infrastructure like washeries).

- Proposed establishing of FDI in sectors like aviation, media (animation, AVGC) and coverage in conclave with all stakeholders.

- $100 \%$ FDI is authorized for insurance intermediaries to offer a lift to the area and attracting extra price range.

- FDI inflows reap an avenue map to advantage its motive of US\$ 100 billion well worth. 
- Encourages FDI within the market model of e-trade. Similarly, the FDI policy for e-commerce location has been advanced to make sure a diploma gambling system for all members.

- Confined to $25 \%$ of the complete income of the sort of supplier through an e-trade market vicinity entity or its organization businesses.

- Released the country wide virtual Communications policy, 2018 which envisages increasing FDI inflows in the telecommunications zone to US\$ 100 billion done through 2022.

- In 2018, allowed remote places airlines to put money into Air India as much as $49 \%$ with the government authorities approval in which the funding can't exceed directly or indirectly.

- No government approval may be required for FDI as much as an extent of $100 \%$ in actual property broker offerings.

- Further stakeholders ease Foreign Direct Investment (FDI) in defence below the automatic route to $51 \%$ from $49 \%$, to be able to offer a boost to the Make in India initiative and for the employment generation.

\section{CONCLUSIONS}

India's Foreign Direct investment (FDI) is a principal driving force of monetary increase and financial development. By and large authorities attract the priority in particular in growing and transitional economies which emphasis no longer just because it boosts capital formation but also capacity to beautify the exceptional of the capital inventory. FDI in India at numerous sectors can gain through the financial boom and improvement through jobs advent, growth of existing production industries. As according to the RBI record, the sectors that attracted better inflows were carrier quarter, communication and vehicle industry. The FDI fairness inflows for the month of April 2019 and June 2019 is better inflows evaluating with different months it's due to Sectors which attracted most overseas inflows at some stage in the year 201920 of April-June encompass offerings (\$2.8 billion), software and hardware applications (\$2.24 billion), telecommunications ( $\$ 4.22$ billion), and trading ( $\$ 1.13$ billion). The country like Singapore emerged as the most vital supply of FDI in India all through the duration of the primary area of the economic with an investment of $\$ 5.33$ billion which observed by Mauritius ( $\$ 4.67$ billion)

\section{REFERENCES}

1. https://www.fdi.finance/

2. https://www.investindia.gov.in/foreign-direct.in

3. https://www.business-standard.com/budget/article/budget-2020-fdi-in-india-rises-to-284-billion-during-2014-19-says-fm120020100403_1.html

4. https://economictimes.indiatimes.com/

5. www.rbi.org

6. Al-Edary, Adnan Dawood M., and Wisam Neamah Jaafar. "The Impact FDI on the Economic Sectors in Turkey Country (An Econometrics Study by Use Johnson Method for Transformation Data)." International Journal of Applied and Natural Sciences (IJANS) 4.3 (2015):51-64 
7. Ajaegbu, Charles Chidozie. "Promoting foreign direct investment (FDI): The case of Uganda." IMPACT: International Journal of Research in Business Management (IMPACT: IJRBM) 2.4 (2014): 73-94.

8. Priyadarshani, E. D., and S. S. Santhosh. "Awareness on FDI in retail sector in Tirunelveli District." IMPACT: International Journal of Research in Business Management (IMPACT: IJRBM) 2.2 (2014): 85-98.

9. Ajaegbu, Charles Chidozie. "Optimizing the Benefits of Foreign Direct Investment (FDI) into Uganda: The Case for Regulation or Supervision." International Journal of Accounting and Financial Management Research (IJAFMR) 6.2 (2016): 1-20.

10. Said, Foued Ben, and Hanen Ben Ouada Jamoussi. "Direct And Spillover Effects Of Regional FDI on Employment Opportunities in Tunisia: A Spatial Panel Data Approach." International Journal of Economics, Commerce and Research (IJECR) 5.5 (2015):19-32

11. Ajaegbu, Charles Chidozie. "The Ugandan Aproach to the Facilitation of Foreign Direct Investment (FDI): The Need for Some Adjustments." BEST: International Journal of Management, Information Technology and Engineering (BEST: IJMITE) 2.12 (2014): 19-34. 